\title{
SYNERGY BETWEEN EU POLICY AND GOOD MANAGEMENT OF LAND RESOURCES IN BULGARIA
}

\author{
Mihaela Mihailova ${ }^{1}$ Plamena Yovchevska ${ }^{2}$ \\ Agricultural Academy (Bulgaria)
}

\begin{abstract}
Homo sapiens, as the highest biological species, develops and upgrades its ideas about the environment, and changes its behaviour to the natural factor; this way, it changes the institutional norm, which has the greatest impact on human behaviour. Natural ecosystems maintain their balance themselves. Regarding artificial systems such as agro-systems, when the anthropogenic impact violates their adaptive capacity, development becomes unsustainable. The current research is aimed at finding the synergy between EU policy and the management of land resources. The policies with the most influence are the Green Deal and the CAP, and are the main subject of this research. Their impact on land management is shown using a scientific method, and includes the review of literature sources, expert methods, and ad hoc evaluation, plus SWOT analysis. In agriculture, a number of policies have changed in order to create synergies between the biological factor and the institutional environment. There is potential for synergy between policy and good management.

KEY WORDS: EU policy, land management, CAP, Green Deal.
\end{abstract}

JEL CODES: Q18, Q57, O38.

DOI: http://dx.doi.org/10.15181/rfds.v34i2.2249

\section{Introduction}

Research problem: The European Policies and the new Green Deal have synergies with good land management, and are about improving the well-being of people, making Europe climate-neutral, and protecting our natural habitats. We highlight the synergies between current policies, and give recommendations for future practices. This is all good for people, the planet and the economy.

Object of the research: Good land management is the object of this research. It is essential for maintaining food security, and a healthy human and animal population, and is highly dependent on good institutional norms/adequate policy. The new deal is a pivotal way of making Europe the leader in creating a new world where the main objectives are the synergic effects between the human population and nature. In Frans Timmerman's words: 'We propose a green and inclusive transition to help improve people's well-being and secure a healthy planet for generations to come.'

Aim of the research: In this research, we aim to find these synergies between land management and use, and the new institutional norm. Land use in Bulgaria for a long period of time has not been properly regulated; because of that, we will look into the effects of good management practices that the CAP policy and the Green Deal are part of. All the goals of EU policy align with the SDG goals of the United Nations.

Mihaela Mihailova - assistant professor, Institute of Agricultural Economics, Agricultural Academy, Sofia, Bulgaria

Scientific fields: agricultural economy, EU policy

E-mail: m.mihailova92@gmail.com

Tel. +359886650003

2 Plamena Yovchevska - professor, Institute of Agricultural Economics, Agricultural Academy, Sofia, Bulgaria

Scientific fields: agricultural economy, EU policy

E-mail: yovchevska@abv.bg

Tel. +359884139836 
The main subjects are land use and policy change, and the article discusses the various synergies between land use and sustainability policies.

Research methodology: The new European policies have created a better synergy between policy and land use, and our purpose here is, by using empirical data, graphics and the ad hoc method, and SWOT, to give a better understanding of the status quo. The methodological framework of the analysis presented in this research article is based on the scientific method. A critical review of literature sources was performed: desk research, logical and expert method, etc, were used to reveal the potential synergy benefits of combining the new institutional norm and land management. We have an EU Bioeconomy Monitoring System that offers a comprehensive overview of European trends in indicators related to the EU bioeconomy. The set of indicators is organised according to a conceptual framework that allows for full coverage of the EU bioeconomy (Kilsedar, Giuntoli, Robert, 2020). The data used from the European Court of Auditors, the National Statistical Institute and the Biodiversity Information System are the main sources of comparable data that have been used for this research to cover all the research topics. The research period is from 2007, since that is the year that Bulgaria joined the $\mathrm{EU}$, and of the management change, and we use the CAP change in 2013 to show the change in policy. Some of the data is from before 2007, so we can compare how the policy changed reality after its implementation.

All the above-mentioned will be used to make a SWOT analysis. A SWOT analysis does this by 'peeling back layers of the company' (Williams, 1996), and is widely used in many organisations. The current analysis is on an institutional level, and has the aim of showing the synergy between good management and land resources in Bulgaria. We use the main policies that have an impact on land quality to construct an adequate picture of the current state of Bulgarian land resources, and point out synergies between policy and land management.

The initials of the acronym and mnemonic SWOT represent the four factors of Strengths, Weaknesses, Opportunities and Threats (Baramuralikrishna, Dugger, 1998).

Williams (1996) claims that effective leaders are people who live 'in a world of SWOT', as they will be individuals who have access to the right information, so that they can act on maximising opportunities and attempt to avoid threats. As such, SWOT analysis is recommended by some as a prime tool of analysis (Hatton et al., 1992).

Within SWOT analysis, the Strengths and Weaknesses are seen as internal factors which are controllable and can be acted upon. The Opportunities and Threats are external, uncontrollable factors. These form the external environment within which the organisation operates, and may include changes in legislation, etc (Hatton et al, 1992). The objective appraisal of strengths and weaknesses should be high on the list of necessary activities (Ansoff, 1957; Cordiner, 1956; Leavitt, 1965, etc). A major objective for many managers is the identification of threats and opportunities through environmental scanning (Jackson, Dutton, 1998).

SWOT analysis has also been referred to by other acronyms or mnemonics. Gray and Smeltzer (1989) refer to a 'WOTS-UP' analysis. WOTS-UP analysis should 'suggest strategies for the firm and supply information for evaluating alternative strategies'. This should lead to the choosing of an optimal strategic plan. Alternatively, to some people it is known as a 'TOWS' analysis, where the emphasis is more on environmental factors (threats and opportunities) than on those which are internal (Hindle, 1994).

\section{Results and discussion}

The main policies we will discuss in this article are EU policy, and mostly the CAP policy and the Green Deal. The CAP's main aim is to regulate land management in agriculture, and present landowners with incentives for better practices that preserve and protect both humans and habitats. In Bulgaria, because of the lack of regulation, much of the land has been overused, the rotation principle has not been applied, and land has erosion problems or has traces of pesticides that are forbidden in the European Union. Natural ecosystems maintain their balance themselves, i.e., they restore the equilibrium of their components (Yovchevska, 2007; Mantarova, 2020). Land is arguably the world's most important natural resource. It provides a host of public and private goods, and humankind has played a large role in shaping its evolution over the millennia (Ramankutty et al., 2006). Regarding artificial systems such as agro-systems, when the anthropogenic impact 
violates their adaptive capacity, development becomes unsustainable. More and more farmers and landowners have turned to the bioeconomy and circular economy, which are more nature-friendly, and have higher added value, both social and economic, and have a substantial part in good land management practices. The main aim of the Green Deal adds to the aim of the CAP, in preserving and strengthening the natural systems, and as part of it, agricultural lands have a central role in preserving land resources, with good management. Another policy that has an impact on good land management is the new EU Biodiversity Strategy for 2030, and the associated Action Plan (annex), a comprehensive, ambitious, long-term plan for protecting nature and reversing the degradation of ecosystems. It aims to put Europe's biodiversity on a path to recovery by 2030, with benefits to people, the climate and the planet, and is a core part of the European Green Deal. The biodiversity strategy is an ambitious and long-term plan to protect nature and reverse the degradation of ecosystems. The 2030 Agenda for Sustainable Development, adopted by all United Nations member states in 2015, provides a shared blueprint for peace and prosperity for people and the planet, now and into the future, and heavily influences any policy created by the EU. All the policies mentioned have a role in good land management, and we are researching the synergy between them.

\subsection{Biodiversity strategy synergy with land resources}

The European Economic Area Financial Mechanism 2009-2014, through the programme BG03 Biodiversity and Ecosystem Services, funded the national scale mapping and assessment of ecosystems and ecosystem services outside NATURA 2000 at the EUNIS 3 level. The Green Deal and the New Biodiversity Strategy are now aiming to further the protection of natural habitats. Currently there are 1,388 protected areas in Bulgaria: $40.97 \%$ of land, and $8.01 \%$ of marine waters. Of the 1,388 protected areas, 341 are Natura 2000 sites, 120 are Special Protection Areas (Birds Directive), and 90 are Sites of Community Importance (Habitat Directive), as well as 1,047 sites designated under national laws. The protected area network in Bulgaria is strongly influenced by Natura 2000 sites, which make up $64 \%$ of the total area protected. In the years after Bulgaria became a member of the EU, because of the CAP and the bigger market for agricultural production, the arable land in the country increased by $12.74 \%$. This has had an effect on biodiversity and natural habitats, as it is equal to 393,000 hectares. A bigger area used for agriculture means a smaller area protected by laws and included in protected land for biodiversity and special habitats.

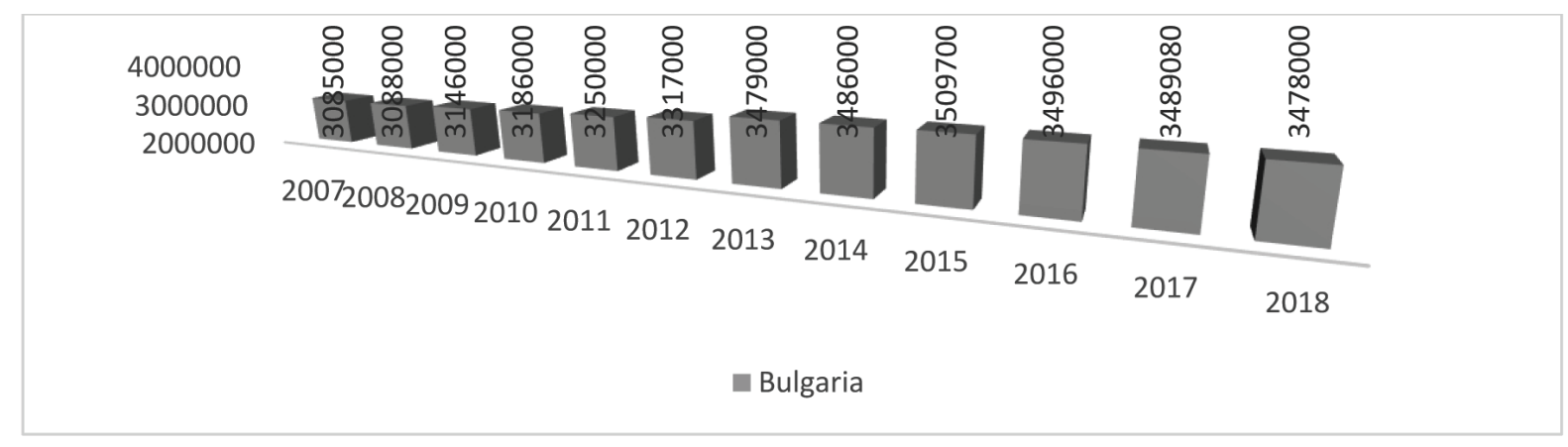

Figure 1. Arable land in Bulgaria (ha)

Source: National Statistical Institute.

Species protected in Bulgaria under EU law are protected under the Habitats Directive and under the Birds Directive. The Habitats Directive has a total of 2,500 species on its list, the Birds Directive has a total of 500 species of wild birds. Habitats protected in Bulgaria under EU law are protected under the Habitats Directive. In Bulgaria, the size of the distribution of land protected is disproportional. Most of the protected 
land is under 100 hectares, and that makes it hard for the protected area not to be influenced by nearby areas that are not under protection. Animal habitats should have a bigger area for the effective protection of their food sources and homes and easy migration. Many of these areas are surrounded by areas that are used for agricultural purposes and use pesticides, have no noise control, and have a high human interference, which leads to fewer numbers of species that inhabit the small protected areas. The Commission's proposals are oriented towards stimulating a sustainable and competitive agricultural sector that can contribute significantly to the European Green Deal, especially with regard to the farm to fork strategy and biodiversity strategy.

The Commission has set out nine specific objectives in order to reach these goals:

- Ensure a fair income for farmers - Increase competitiveness $\bullet$ Rebalance the power in the food chain - Climate change action $•$ Environmental care $\bullet$ Preserve landscapes and biodiversity $\bullet$ Support generational renewal $\bullet$ Foster vibrant rural areas $\bullet$ Protect food and health quality

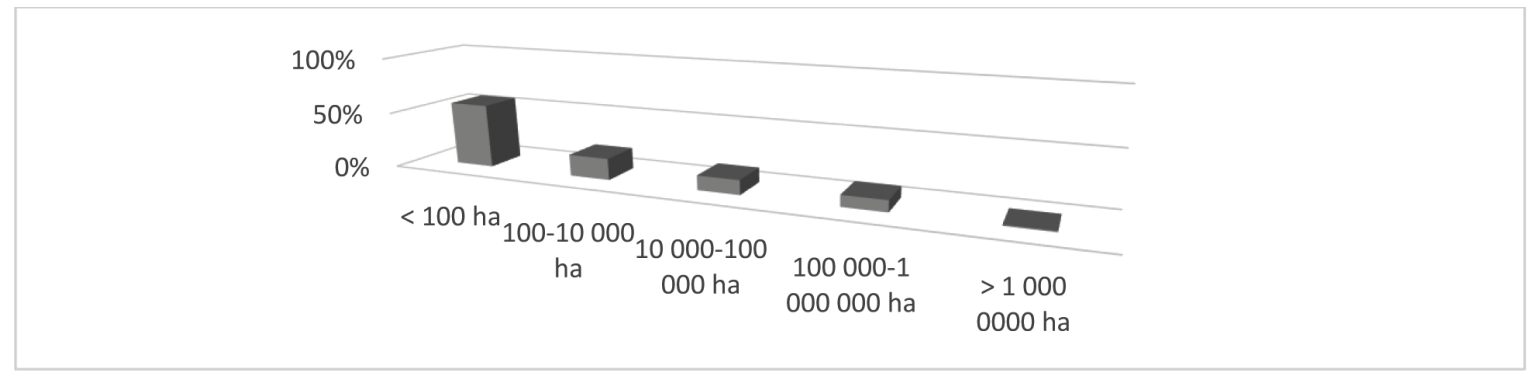

Figure 2. The size distribution of Bulgaria's areas of protected land

Source: The Biodiversity Information System for Europe.

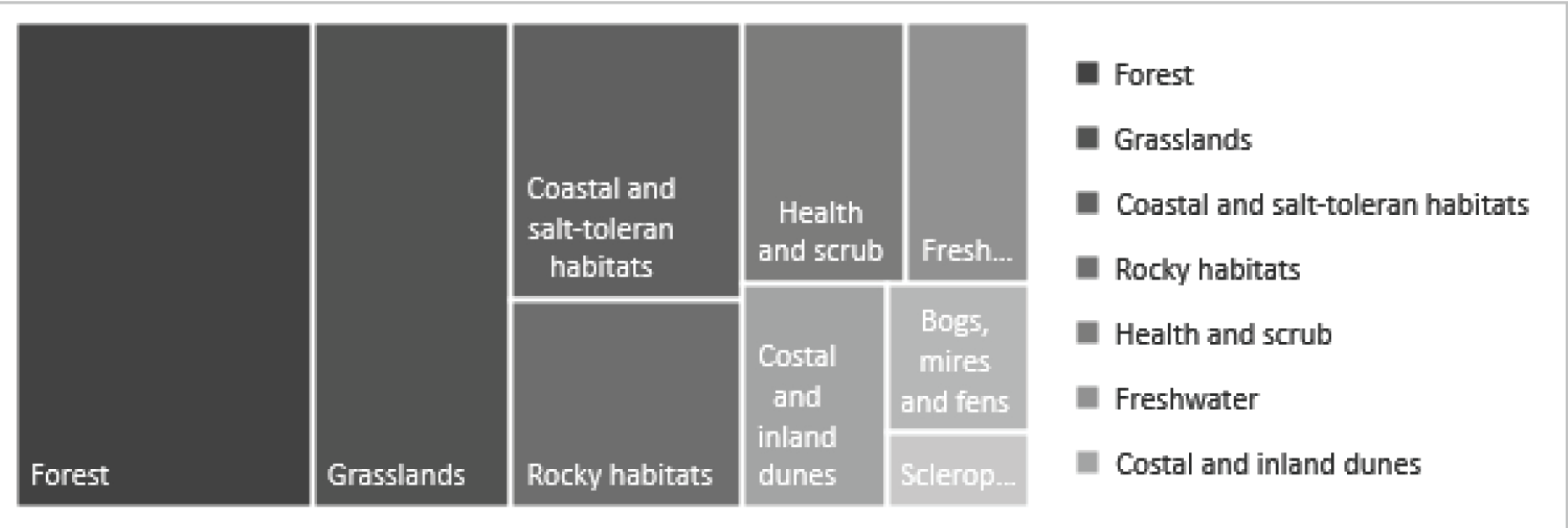

Figure 3. Habit composition by group in Bulgaria

Source: The Biodiversity Information System for Europe.

Most of the land under protection is forest, and then grasslands. Even so, the distribution of land is too uneven for us to see a synergy between the policy implemented and land use. In the future, the preservation area should be bigger for a better effect on biodiversity. In Bulgaria, which is still widely considered to have rich biodiversity (due to, among other things, more traditional non-intensive farming practices and smaller farms), some studies have concluded that it was sufficient to maintain the existing biodiversity status, regardless of the fact that better practices would have better results. 


\subsection{The impact of CAP policy and land management}

Periodical reforms of the CAP have yet failed to deliver a level of change that is not for a better and sustainable economy based on better management and new practices. The environment has come to take an important position in discussions about rural land policy. The government has identified and designated the most valuable habitats through a comprehensive system of protected areas. The successful development of agriculture (namely crop productive agro-systems) is determined by interaction between the production potential (soil fertility) of agricultural land and the respective regional agroecological structures of crop growing, through which the land, as the main factor in production, is used under market conditions. The rational use of the adaptive potential of agricultural crops in relation to the respective ecological conditions leads to an increase in natural economic indicators and production quality when applying optimal technological solutions in the cultivation of the respective crop species. The application of technological solutions in accordance with the characteristics of the biological factor has a nature-friendly impact, leads to relatively low production costs, and ensures the sustainability of agricultural production. There is an opportunity for the synergic impact appearance between the biological factor and the production technology. The potential benefits are multiplied by a combination of the biological factor characteristics and the optimal technological solutions, adapted by the agricultural actors to the specific object of economic activity. When combining these conditions, a synergistic effect is manifested, which strengthens the socio-economic result of the economic activity in an action that protects the natural environment. These are principled paradigms that are valid in all societies. Bulgaria is endowed with monopolistic qualities for the production of agricultural products. Under field conditions, more than 144 cultivated plant species can be produced under the open sky. The European Court of Auditors, regarding the CAP, considers that it is part of the problem and not the solution to it. The ECA discloses that the greening and cross-rescue requirements under the CAP are not successful in providing information on biodiversity in agricultural land. Furthermore, the CAP first pillar and its direct payments have been an incentive for Bulgarian agriculture to produce fewer and fewer types of crops, which lowers diversification and can lead to bad land management and the overuse of land resources. The intensification of farming is one of the main culprits of bad land management and lower biodiversity. As we can see in Figure 4, the percentage of farms with higher input (intensity) has risen drastically since the introduction of EU policy in Bulgaria. To counter this process, in the 2013 the new CAP introduced greening. Forest protection and biodiversity are strengths in Bulgarian conservation (Mihailova, 2020).

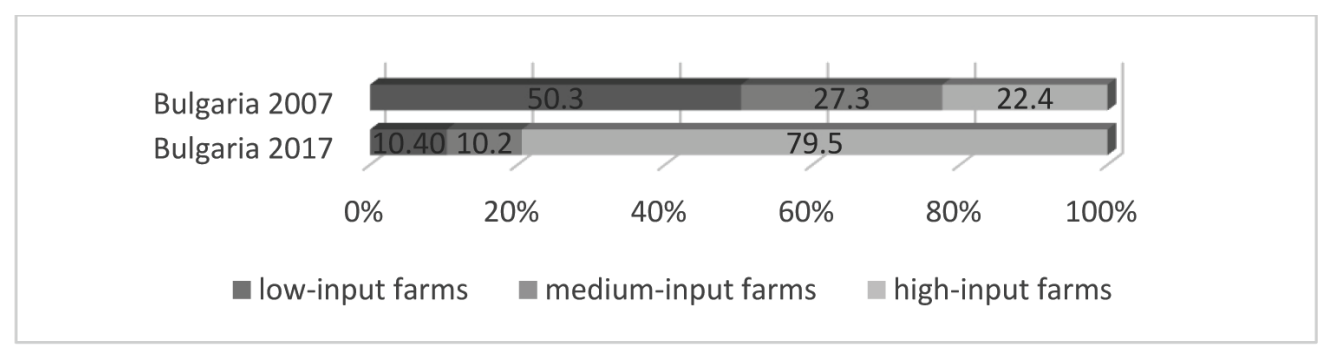

Figure 4. Intensification of farming by \% of utilised agricultural area (2013 to 2017)

Source: EU Bioeconomy Monitoring System dashboard. 


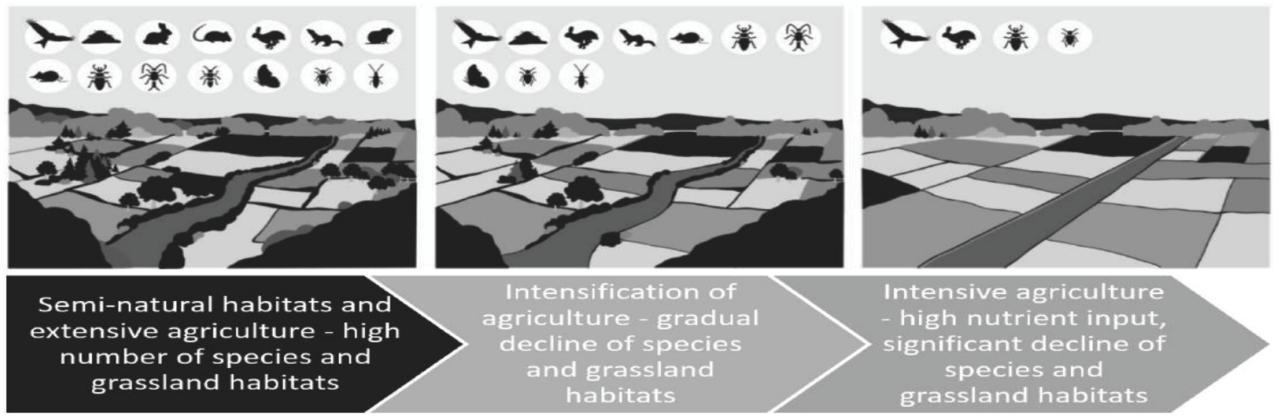

Figure 5. The decline in farmland biodiversity due to the intensification of land use

Source: Sustainable use of plant protection products.

Areas that are used for agricultural purposes have faced numerous challenges when it comes to sustainability, there are dynamic changes in problems, and that is countered by the dynamic change in EU policy. In many farmed areas, the number of species living there has declined. Farmland bird populations are considered to be a good indicator of changes in farmland biodiversity, because birds play a significant role in the food chain, and are found in many varied habitats. In agricultural land where there is intensive farming, there is a rapid decline in the bird population. Like birds, butterflies occur in a number of habitats, and respond rapidly to changes in environmental conditions. The Commission Staff Working Document, accompanying the mid-term review of the biodiversity strategy 2020, states that butterflies are representative of many other insects. In places where intensive farming is far more common, scientists see a need to re-establish biodiversity in areas where species and rich natural habitats have disappeared in recent decades (Erisman, 2016). In March 2020, the Commission published an evaluation report on the impact of the CAP on habitats, landscapes and biodiversity (Alliance Environment, 2019). Agriculture markedly intensified after the country joined the EU in 2007, as is shown in Figure 4 and Figure 5, more and more land is allocated to high-input farms, and that has an impact on biodiversity. This may put the population of birds and insects at risk, and points out flaws in the policies that take centre stage in species preservation. The impact assessment of the Commission's legislative proposals for the 2014 to 2020 CAP acknowledged the importance of incorporating biodiversity concerns into the agricultural sector to meet the agriculture target of the biodiversity strategy. The new CAP 2021-2027 proposals aim to foster a sustainable and competitive agricultural sector which can contribute significantly to the European Green Deal, especially with regard to the farm to fork strategy and biodiversity strategy, and that has the potential for higher synergy between policy and good management.

Farmers play a key role in tackling climate change, protecting the environment and preserving landscapes and biodiversity. The European Commission aims to facilitate the role of farmers, by ensuring that the CAP contributes to climate change mitigation and adaptation as well as sustainable energy, fosters sustainable development and the efficient management of natural resources such as water, soil and air, contributes to the protection of biodiversity, enhances ecosystem services, and preserves habitats and landscapes.

\subsection{The Green Deal and the CAP: the future of land use}

In its proposals, the Commission sets out a new green architecture for the CAP, featuring strengthened mandatory requirements and increased funding opportunities for green farming. Among the measures foreseen in the proposals are the preservation of soil, through requirements to protect carbon-rich wetlands, practise crop rotation, and an obligatory nutrient management tool designed to help farmers improve water quality and reduce ammonia and nitrous oxide levels on their farms. A new stream of funding from the CAP's direct payments budget for 'ecoschemes' will support and incentivise farmers to undertake agricultural practices beneficial to the climate, biodiversity and the environment. A big role in furthering the impact of good land management are bioeconomy and the circular economy, which are part of the new EU policies. The bioeconomy aims at the transition of the economy 
and society from a fossil base to a renewable resource base (Priefer, 2017). Spatial planning, with its systemic and cross-sectoral approach, which is aimed at balancing spatial aspects and the land use demands of environmental, social and economic development (Stöglehner, 2019), can support the transition to a bioeconomy, also in line with sustainable development, as framed in the Sustainable Development Goals (SDGs).

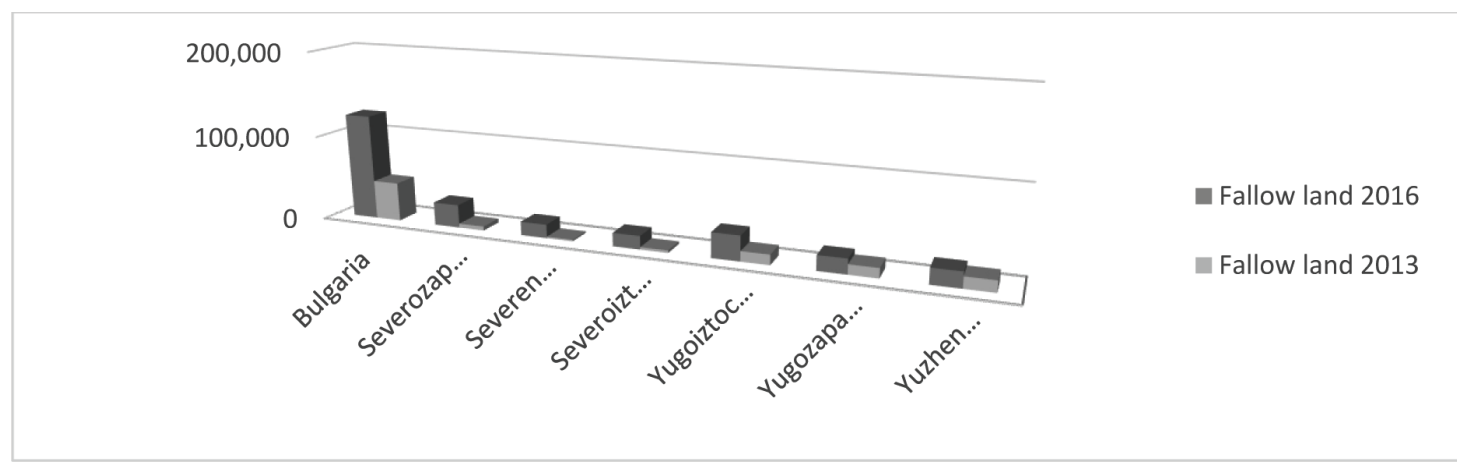

Figure 6. Fallow land in Bulgaria

Source: National Statistical Institute.

Around half of the European Union's area is farmed land. Farmers act as managers of the countryside, they shape landscapes, and through their work, they provide public goods that are beneficial to all. However, farmers also depend on natural resources, such as soil and water, for their living. Farming activities are affected by climatic events, the state of the environment, biodiversity, and water quality. The 'green direct payment' (or 'greening') supports farmers who adopt or maintain farming practices that help meet environmental and climate goals. Through greening, the European Union (EU) rewards farmers for preserving natural resources and providing public goods which are of benefit to the public but are not reflected in market prices.

Farmers receive the green direct payment if they comply with three mandatory practices that benefit the environment (soil and biodiversity in particular). The three actions farmers have to put in place are: crop diversification (a greater variety of crops makes soil and ecosystems more resilient); maintaining permanent grasslands (grassland supports carbon sequestration and protects biodiversity/habitats); dedicating 5\% of arable land to areas beneficial for biodiversity (Ecological Focus Areas, or EFA), such as trees, hedges or land left fallow that improves biodiversity and habitats.

In Bulgaria, because of greening, the fallow land has increased three times since 2013 when the CAP policy was introduced to 2016, as is shown in Figure 6. This allows farmers to let land sit ploughed and free of weeds, without adding anything throughout the growing season (called unoccupied fallow). In other words, the soil is left to be cleaned of weeds, and is not loaded with either artificial or revolving fertilizer. It makes farmers lose money from loss of production, but is helpful in keeping the land fit for agricultural purposes. The green measures allow farmers to use the practice to rent the land without the economic burden. This, on the other hand, helps with soil erosion and contamination.

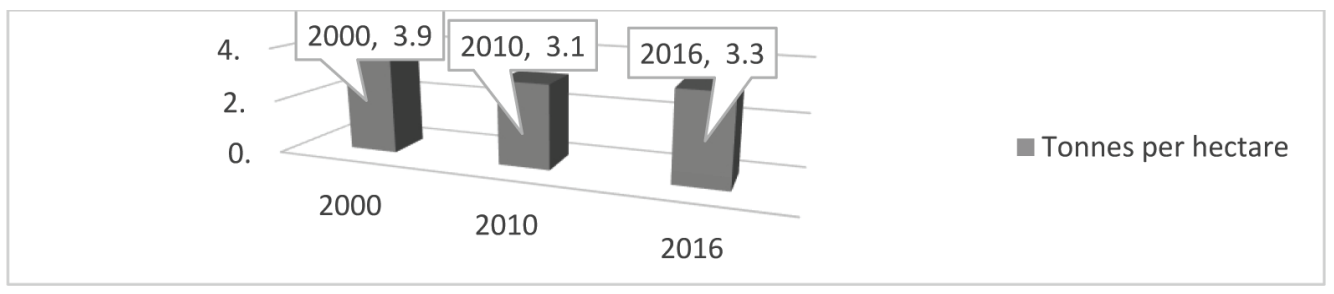

Figure 7. Soil erosion in Bulgaria

Source: Eurostat. 
Processes like desertification, erosion, the decline in organic matter in soil, soil contamination (e.g. by heavy metals), soil compaction and salinity can reduce the ecological state, and thereby the productive capacity, of the soil. This degradation can result from inappropriate farming practices, such as unbalanced fertilization, the excessive use of groundwater for irrigation, improper use of pesticides, the use of heavy machinery, and overgrazing. In 2006, the European Commission adopted a soil protection thematic strategy, including a proposal for a soil framework directive, aimed at the preservation of soil functions, the prevention of soil degradation, and the restoration of degraded soils. Conservation agriculture is set to play a central role in the green architecture of the post-2020 Common Agricultural Policy (CAP). Conservation Agriculture (CA) lends itself easily to misinterpretation, as the term 'conservation' often indicates activities involving the preservation and restoration of degraded natural habitats to improve biodiversity. However, although CA also promotes biodiversity, it mostly addresses issues referring to a different phenomenon: soil degradation. Soil organic matter has been increasingly depleted, thanks to land-use intensification and mono-cultures, while the use of heavy machinery stresses the soil by causing ground compaction. CA works to address this via a suite of farming practices designed to avoid physical degradation, such as growing a permanent protective plant cover on the soil, and advocating for an agricultural production system based on a total or partial reduction of ploughing and tilling. According to the European Conservation Agriculture Federation (ECAF), the agronomic practices included in CA are based on three core principles to be fulfilled concomitantly: minimum soil disturbance, maintenance of permanent soil covers, and cropping system diversity. Around $2.11 \%$ of Bulgaria's total surface area is at very great risk of water erosion (Robert, 2012). The severity of soil erosion and mean soil loss have recently tended to decline as a result of good practices, and mainly areas that are under severe erosion risk have been observed particularly along the slopes of the Balkan Mountains and the Rhodope Mountains. For the time being, the levels of soil erosion in Bulgaria are stable, and good practices and good land management have helped keep them lower, on a level similar to the average in the EU.

\subsection{Social factors for the better management of land resources}

In Bulgarian agriculture, there are deep socio-cultural traditions that have the potential to reap synergistic benefits. This is evidenced by the results of an empirical sociological survey 'Environmental Culture of Producers in Agricultural Production'. In 2010, farmers in the Blagoevgrad region, known for small-scale production, were surveyed using the face-to-face method (Yovchevska, 2010). In 2012, a survey was conducted using the same method among registered agricultural producers throughout the country. The results of the answer to the question 'What is more important for you?' are indicated in Figure 8.

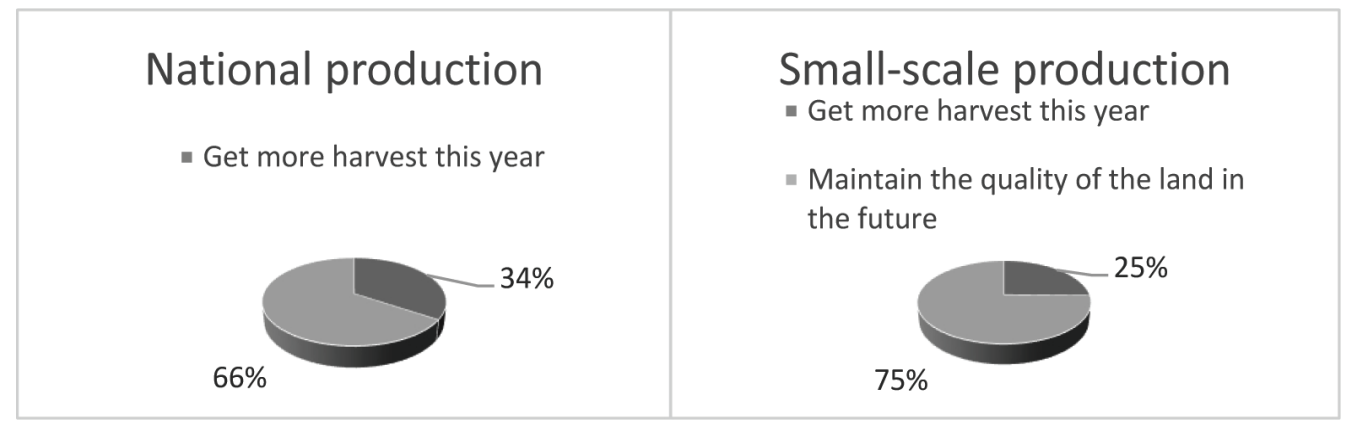

Figure 8. What is more important for you?

Source: Empirical sociological survey ‘Environmental Culture of Producers in Agricultural Production’.

The pro-ecological behaviour of farmers is analysed on the basis of the results of the empirical sociological study 'Ecological Culture of Agricultural Producers'. One field study conducted in 2010 is representative of the residents of villages in Blagoevgrad over 18 years of age. The area is known for its 
small-scale production. The second field study is nationally representative. It was held in 2012 among registered agricultural producers. The purpose of the regional and national ESI is to gather information on the ecological culture of the farmers relevant to production activity. The research was carried out as part of the project 'Transformation of the National Value System and its Synchronisation with European Models: The Development of Environmental Culture as an Indicator of Translation of European Values in Bulgarian Society' (2009-2012) led by Professor Anna Mantarova from the Institute of Sociology at the Bulgarian Academy of Sciences.

The data are representative and reflect the perceptions of producers in Bulgarian agriculture about the importance of the land resource in the coordinate system of producer-public benefits. When we asked farmers if they want to get more production in the current year, or to preserve the quality of the land in the future, we get three-quarters positive answers in the dreadnought production, and two thirds of respondents in the national survey.

In 2021, as part of the POZESIN project, a nationally representative ESI will be held in order to apply the chronotopia method, to check the dynamics of farmers' attitudes in view of the policies incorporated in the Green Deal, and the possibility to reveal synergy benefits from the good management of land resources in Bulgarian agricultural holdings. With the help of the chronotopia, we will establish the dynamics and sustainability of the attitude of the actors in Bulgarian agriculture to green policies/green architecture in the CAP, given the sociocultural phenomenon registered in the previous ESI for sparing land as an indispensable factor in the primary sector. This will analyse one of the possibilities for synergy between community policy and individual economic practices in agriculture.

\subsection{SWOT analysis}

The current SWOT is based on research on current synergies found, and has the aim of showing current strengths and weaknesses with which to form future opportunities and threats.

Table 1. SWOT analysis

\begin{tabular}{|c|c|}
\hline Strengths & Weaknesses \\
\hline $\begin{array}{l}\text { Bulgaria still has rich biodiversity (due to, among other } \\
\text { things, more traditional non-intensive farming practices } \\
\text { and smaller farms) } \\
\text { Bulgaria currently has not moved to intensive } \\
\text { agriculture which helps the preservation of land } \\
\text { Soil erosion is happening mainly in mountain regions } \\
\text { There is a social factor that has not changed, and aims } \\
\text { at land preservation in agriculture and land protected } \\
\text { areas }\end{array}$ & $\begin{array}{l}\text { There is a process of intensification in agriculture } \\
\text { More species and land are being lost due to agriculture, } \\
\text { because the land use for this purpose has risen significantly } \\
\text { CAP policy stimulates farmers to look for more land, and the } \\
\text { agricultural land utilised has risen } \\
\text { Soil organic matter has been increasingly depleted, thanks to } \\
\text { land-use intensification and mono-cultures } \\
\text { The CAP first pillar is hindering good management, because } \\
\text { it aims at utilising more land }\end{array}$ \\
\hline Opportunities & Threats \\
\hline $\begin{array}{l}\text { Bulgaria has great biodiversity that can easily be } \\
\text { preserved } \\
\text { There is an opportunity for the synergic impact } \\
\text { appearance between the biological factor and production } \\
\text { technology } \\
\text { The 'green direct payment' (or 'greening') supports } \\
\text { farmers who adopt or maintain farming practices that } \\
\text { help meet environmental and climate goals }\end{array}$ & $\begin{array}{l}\text { If the policy does not change, moving continuously towards } \\
\text { intensive agriculture, there is a higher chance of bad land } \\
\text { management and a lack of synergy between nature and land } \\
\text { More and more land and biodiversity can be lost due to the } \\
\text { small size of land under protection. Future policies should } \\
\text { find a way to cluster land } \\
\text { Policies have not taken into consideration the current } \\
\text { problems, and are made on an EU basis not specific to every } \\
\text { country }\end{array}$ \\
\hline
\end{tabular}

Source: Created by the author. 


\section{Conclusions}

The policy implemented by the EU is constantly changing, because of the dynamic effect it has on land management and land use. In general, EU policy aims to have a positive effect on humans, animals and nature, but the CAP has a negative effect that was not factored/understood before the implementation. The CAP auditors consider that the CAP is part of the problem, not always the solution to it. During the new CAP period, there should be strict monitoring on good management and policy implementation, so that the negative effects of the policy can be eliminated. The constant changes in policies are so that policymakers can counter and create solutions for longstanding problems and problems caused by current policies. The constant evolution helps to create a more sustainable and stable environment. The ECA concludes that the greening and cross-rescue requirements under the CAP are not successful in tackling biodiversity on agricultural land, and more effort should be put into bigger protected areas and the negation of closeness to agricultural land. The European Court of Auditors also found that the negative impact on costs that leads to increased emissions and can therefore accelerate climate change has not been taken into account, especially in the network of agricultural and cohesion policy. A new stream of funding from the CAP's direct payments budget for 'eco-schemes', which will support and incentivise farmers to adopt agricultural practices beneficial to the climate, biodiversity and the environment is needed. Biodiversity has been a central part of all the policies, and is influenced by any human activity; the focus has shifted from preservation to stimulating and creating habitats that will ensure greater biodiversity, including, in agriculture, for example, the creation of cluster/tiny forests created by Akira Miyawaki. The preservation of land and good management should be created by good practices and spreading awareness and stimulus for landowners and farmers, thus creating synergy for humankind and nature. With the help of SWOT, we have shown the opportunities, weaknesses and threats, and they should be the main focus of future policy creation. We have found synergies and potential for synergies between CAP policy, greening and biodiversity, but having a good socio-cultural tradition can help the transition to better land management.

\section{Acknowledgements}

The author thanks the Scientific Research Fund for its support in carrying out work on the POZESIN 'Land Relations and European Policy: Synergy and Prospects for Bulgarian Agriculture' project, contract No КП-06-H35/2-18.12.2019, National Research Fund at the Ministry of Education and Science of Bulgaria.

\section{References}

Alliance Environment. (2019). Evaluation of the impact of the CAP on habitats, landscapes, biodiversity. November. Ansoff, H. I. (1957). Strategies for Diversification. Harvard Business Review, Vol. 35, Issue 5, p. 113-124.

Baramuralikrishna, R., Dugger, J. C. (1998). SWOT Analysis: A Management Tool for Initiating New Programs in Vocational Schools. Scholarly Communications, University Libraries. Available on line: http:// vega.lib.vt.edu/ejournals/ JVTE/v12n1.

Biodiversity on farmland: CAP contribution has not halted the decline. (2020). Sustainable use of plant protection products: limited progress in measuring and reducing risks (special report 05/2020). More efforts needed to implement the Natura 2000 network to its full potential (special report 01/2017).

Cordiner. (1956). New frontiers for professional managers. McKinsey Foundation lecture series. ASIN: B0006AUTV4.

Commission Communication to the European Parliament, the European Council, The Council, The European Economic and Social Committee and the Committee of the Regions. (2019). The European Green Deal, COM//640 final.

Gray, E. R., Larry R., Smeltzer, L. R. (1989). Management: The Competitive Edge. Macmillan. University of Indiana. ISBN:0023461802, 9780023461804.

Erisman et al. (2016). Agriculture and biodiversity: a better balance benefits both. AIMS Agriculture and Food, Vol. 1(2). BfN: "Agriculture Report: Biological diversity in agricultural landscapes", 2017.

EU Bioeconomy Monitoring System dashboard. Available on line: https://knowledge4policy.ec.europa.eu/visualisation/ eu-bioeconomy-monitoring-system-dashboard_en

European Commission. (2019). What is the European Green Deal? Available on line: https://ec.europa.eu/commission/ presscorner/detail/en/fs_19_6714 
European Commission. (2019). The 2030 EU Biodiversity Strategy. Available on line: https://ec.europa.eu/environment/strategy/biodiversity-strategy-2030_en

European Commission and European Environment Agency. (2021). The Biodiversity information system for Europe. Available on line: https://biodiversity.europa.eu/countries/bulgaria

Jackson and Dutton. (1998). Discerning Threats and Opportunities. Administrative Science Quarterly, Vol. 33(3). Doi: $10.2307 / 2392714$.

Giuntoli, J., Robert, N., Ronzon, T., Sanchez Lopez, J., Follador, M., Girardi, I., Barredo Cano, J., Borzacchiello, M., Sala, S., M'Barek, R., La Notte, A., Becker, W., Mubareka, S. (2020). Building a monitoring system for the EU bioeconomy. EUR 30064 EN. Publications Office of the European Union, Luxembourg. ISBN 978-92-76-15385-6. Doi: 10.2760/717782. JRC119056.

Hatton, A., Sedgmore, L. (1992). Marketing for College Managers: A Workbook for the Effective Integration of Marketing into College Planning. Staff Coll., Bristol (England). Staff College, Coombe Lodge, Blagdon, Bristol. England BS18 6RG.

Kilsedar, C., Wertz, S., Robert, N., Mubareka, S. (2021). Implementation of the EU Bioeconomy Monitoring System dashboards. Knowledge Centre for Bioeconomy. Ispra. ISBN 978-92-76-28946-3 (online). Doi:10.2760/577115 (online). JRC123675.

Koch, A. (2000). SWOT does not need to be recalled: It needs to be enhanced. Swinburne University of Technology.

Leavitt, H. J. (1965). Applied organisational change in industry: Structural, technological and humanistic approaches. In J. G. March (ed.). Handbook of organisation. Rand McNally and Company. Chicago, Illinois.

Mantarova, A. (2020). Practices and problems in biodiversity conservation in the Natura 2000 eco-network. Sustainable development: inter- and intragenerational aspects. (Ustoicivo razvitie: inter- i intrageneratsionni aspecti.) Sofia: Avangard Prima, p. 145-172. ISBN 978-619-239-464-6.

McCormick, K., Kautto, N. (2013). The Bioeconomy in Europe: An Overview. Sustainability, Vol. 5, p. $2589-2608$.

Mihailova, M. (2020). The state of agriculture in Bulgaria - PESTLE analysis. Bulgaria Journal of Agricultural Sciences, Vol. 26(5), p. 935-943.

Özşahin, E., Eroğlu, I. (2019). Soil erosion risk assessment due to land use/cover changes (LUCC) in Bulgaria from 1990 to 2015. Alınteri Zirai Bilimler Dergisi, Vol. 34(1), p. 1-8. Doi: 10.28955/alinterizbd.444193

Priefer, C., Jörissen, J., Frör, O. (2017). Pathways to Shape the Bioeconomy. Resources, Vol. 6 (10).

Ramankutty, N., Graumlich, L., Achard, F., et all (2006). Global Land-cover Change: Recent Progress, Remaining Challenges. In E. F. Lambin, H. Geist (eds.). Land Use and Land Cover Change, Springer, p. 9-39. Berlin. Doi: http://dx.doi.org/10.1007/3-540-32202-7_2.

Ribeiro, S. (2018). Opinion on the next MFF: Preparing the Parliament's Position on the MFF post-2020 AGRI_AD (2018) 612377.

Robert, P. (2012). Universal Soil Loss Equation (USLE). Soil Management/OMAFRA; Don Hilborn, P.Eng. - Engineer, By-Products \& Manure/OMAFRA http://www.omafra.gov.on.ca/english/engineer/facts/12-051.htm

Special Report European court of auditors. (2020). Protection of wild pollinators in the EU - Commission initiatives have not borne fruit. Available on line: https://op.europa.eu/webpub/eca/special-reports/pollinators-15-2020/en/index.html

Stöglehner, G. (2019). Conceptualising Quality in Spatial Planning. Raumforsch. Raumordn, Vol. 77, p. 1-15.

Yovchevska, P. (2007). The European ecological network NATURA 2000 - an opportunity for sustainable development of the Bulgarian nature. European integration and sustainable development. (Evrointegracia $i$ ustoychivo razvitie.) Sofia: Iztok-Zapad, p. 157-172. ISBN: 978-954-321-404-4

Williams (1996). Marketing: Mastering Your Small Business. Publishing: Kaplan Business ISBN-13:978-1574100204.

Йовчевска, П. (2010). Екологичен императив и традиционни земеделски практики: взаимовръзки и синергия. Екологичната култура в модернизиращуото се общество. Авангард прима, с. 121-150. 


\title{
ES POLITIKOS IR ŽEMĖS IŠTEKLIŲ VALDYMO SINERGIJA B U L G A R I J O J E
}

\author{
Mimaela Minailova, Plamena Yovchevska
}

Žemès ūkio akademija (Bulgarija)

\section{Santrauka}

Homo sapiens, kaip aukščiausia biologinè rūšis, plètoja ir tobulina savo aplinkos išsaugojimo idejjas. Šiuo metu tam tikra žmonių dalis keičia savo elgesị, kad kuo mažiau kenktų gamtai, tai ypač veikia organizacijų elgesị. Žemès išteklius galima skirstyti ị natūralias ir dirbtines žemès išteklių sistemas. Natūralios ekosistemos geba išlaikyti pusiausvyrą, t. y. pačios ją atkuria. Dirbtinių sistemų, pavyzdžiui, agrosistemų, atveju dèl antropogeninio poveikio pažeidus žemès išteklių prisitaikymo galimybes, plètra tampa netvari. Šiuo tyrimu ieškoma ES politikos ir žemès išteklių valdymo sinergijos. Čia ypač svarbi ES „Žalioji sutartis“ ir bendrijos žemès ūkio politika (BŽŪP), tai yra pagrindinè pokyčių varomoji jèga, kurią ir aptarsime. Jų poveikis žemės valdymui nustatytas išanalizavus literatūros šaltinius, atlikus ekspertų apklausą, grafinių metodų bei ad hoc vertinimo ir stiprybių, silpnybių, galimybių bei grèsmių analizę. Siekiama išsiaiškinti, kuri politika teigiamai, o kuri neigiamai veikia žemės valdymo procesus. Žemės ūkio svarbos fizinei gyventojų sveikatai požiūriu pastaraisiais dešimtmečiais pakeista keletas politikos krypčių, siekiant biologinio veiksnio ir institucinès aplinkos, kurioje veikia pagrindinio sektoriaus subjektai, sinergijos.

Tvaraus vystymosi darbotvarkè iki $2030 \mathrm{~m}$., kurią visos Jungtinių Tautų valstybės narės prièmė $2015 \mathrm{~m}$., apėmė bendrą taikos ir žmonių bei planetos klestejjimo planą dabar ir ateityje. ES politika kelia darnaus vystymosi tikslus, siekiant tvaraus žmonių, gyvūnų ir gamtos sistemos vystymosi. Europa savo vykdoma veikla neturètų skatinti klimato atšilimo, taip išsaugotų natūralią buveinę, tai būtų naudinga žmonèms, planetai ir ekonomikai. Pagrindinis BŽŪP tikslas - reguliuoti žemės valdymo žemės ūkyje procesus, skatinti žemės savininkus taupiai ir racionaliai naudoti žemès ūkị, siekiant išsaugoti žemę, nekenkti gyvūnams ir žmonèms, kuo daugiau naudoti atsinaujinančių išteklių.

PAGRINDINIAI ŽODŽIAI: ES politika, žemès valdymas, bendroji žemès ükio politika.

JEL KLASIFIKACIJA: Q18, Q57, O38.

Received: 2021-03-06

Revised: 2021-04-28

Accepted: 2021-05-04 